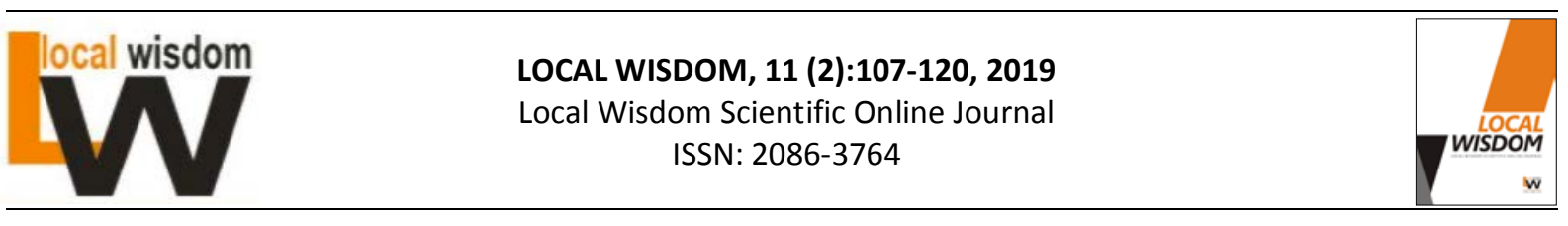

\title{
Typology of Fasade Building in Kayu Tangan Street Corridor, Malang City
}

\section{Resti Piutanti ${ }^{*}$}

1. Magister Architecture, University of Brawijaya, Malang, Indonesia

Corresponding Author: restipiutanti@gmail.com

\begin{tabular}{|c|c|}
\hline & Abstract \\
\hline \multirow[t]{2}{*}{$\begin{array}{l}\text { Keywords: } \\
\text { typology, buildings } \\
\text { facade, street corridor }\end{array}$} & $\begin{array}{l}\text { The Kayu Tangan Street Corridor is one of the areas that play an important } \\
\text { role for Malang City. Building facade in this road corridor has significance } \\
\text { in creating the visual character of Malang. The facade is an important } \\
\text { architectural element of buildings because it can show the function and the } \\
\text { significant meaning of the building. This study aims to determine how to } \\
\text { classify the type of facade of the existing building in Street Corridor of Kayu } \\
\text { Tangan that will affect the visual quality of this area. This study used a } \\
\text { qualitative approach and descriptive-explorative methods. Selection of the } \\
\text { sample was done by purposive sampling methods based on the buildings } \\
\text { function. This study expected to gain a typology of building facade at Street } \\
\text { Corridor of Kayu Tangan and led the development goal on the area to } \\
\text { preserve the quality of its visual character }\end{array}$ \\
\hline & Abstrak \\
\hline $\begin{array}{l}\text { Kata Kunci: } \\
\text { tipologi, fasade } \\
\text { bangunan, koridor } \\
\text { jalan }\end{array}$ & $\begin{array}{l}\text { Koridor Jalan Kayu Tangan merupakan salah satu kawasan yang memegang } \\
\text { peranan penting bagi Kota Malang. Fasade bangunan yang ada di koridor } \\
\text { jalan ini memiliki arti penting dalam membentuk karakter Kota Malang } \\
\text { secara visual. Fasade merupakan elemen arsitektur yang penting karena } \\
\text { mampu menunjukkan fungsi dan makna bangunannya. Kajian ini bertujuan } \\
\text { untuk mengetahui bagaimana pengklasifikasian tipe fasade bangunan yang } \\
\text { ada di Koridor Jalan Kayu Tangan yang akan mempengaruhi kualitas visual } \\
\text { kawasan. Dalam studi ini, digunakan pendekatan kualitatif dengan metode } \\
\text { pengkajian secara deskriptif - eksploratif. Pemilihan sampel yang dilakukan } \\
\text { adalah dengan purpossive sampling berdasarkan fungsi bangunannya. } \\
\text { Dengan dilakukankannya kajian ini, diharapkan dapat memunculkan } \\
\text { tipologi fasade bangunan di Koridor Jalan Kayu tangan dan memunculkan } \\
\text { arahan pengembangan kawasan guna melestarikan kualitas karakter } \\
\text { visualnya. }\end{array}$ \\
\hline
\end{tabular}




\section{Introduction}

The Kayu Tangan Street Corridor is one of the areas that play an important role for Malang City. This Street is the main axis in the north-south direction, the main traffic lane that connects Malang with the outside of the city. Since the beginning of its construction, it has played an important role as a central trading area. The shape and structure of an area, building masses, landscape elements, and building facades in an area will determine the character of the city visually.

The Kayu Tangan Street Corridor is one of the historic road corridors that form the distinctive character of Malang City, which is visually formed by rows of building facades along Kayu Tangan Street(Fauziah, Nur, Antariksa, 2012). The facade of the buildings lined up along the street corridor gives distinctive characteristics and influences the visual quality of the city. The facade is an important architectural element because it is to show the function and meaning of the building.

Rows of building facades should be able to create an urban environment aesthetically, as well as provide visual comfort for the residents of Malang City (Fauziah, Nur, Antariksa, 2012). It will be very good if this corridor is maintained so that a reference (policy and guidelines) is needed for development and preservation along this street corridor.

The study of building facade typology was conducted to find out how the classification of facade types of buildings in the Kayu Tangan Street Corridor would visually affect the quality of the area. By carrying out this study, it is hoped that the typology of buildings facade in the Kayu Tangan Corridor will be generated and give direction to regional development in order to preserve the quality of its visual character.

In this study, a qualitative approach was used with a descriptive-explorative assessment method. Descriptive methods used to explain and describe the conditions of the Kayu Tangan Street Corridor, especially regarding the typology of building facades. Exploration carried out on the study of typology based on facade elements that will affect the visual character of the region. In addition, it also affects the function typology on building facade characters. The sample selection is nonprobability sampling, using purposive sampling.

The study was conduct based on the results of the literature review, related sources and observations. The sample was choose based on the typology of existing functions and based on previous studies related to the Kayu Tangan Street Corridor. It is done by dividing the perfunction of the building so that the relationship between the function and facade character in the Region will be known.

\section{Literature of Review}

Typology comes from two syllables from Greek, namely typos, which means grouping, and logos, which means science. Literally, it can be said that typology is the study of grouping things in general. According to (Antariksa, 2010), typology is a study relating to the types of several objects that have the same type.

Typology is an activity to study the types of architectural objects, and classify them (place these objects) in a type classification based on similarity in certain things that are owned(Prijotomo, 1997).

Generally, typology is based on the possibility of classifying several objects, because they have similarities in their basic characteristics (Antariksa, 2010). This study studies the types of classifications based on the similarity of object characteristics. Typology can be done if the object 


\section{Tipology of Fasade Building in Kayu Tangan Street Coridor, Malang City \\ Resti Piutanti}

under study has the same characteristics (Galih W. Pangarsa, Ema Y. Titisari, Abraham M. Ridjal, 2012)

Amiuza (2006) in (Antariksa, 2010) states that typology is a concept of describing groups of objects based on the similarity of basic characteristics that try to sort or classify forms of diversity and similarity. Aspects that can be classified can be functions, forms, or styles(Antariksa, 2010). Typology refers to the concept and consistency that can make it easier for people to know parts of the architecture. This means that there are certain types of buildings that will form one character, characteristic or image. There is repetition as a tool for organizing space and form. Almost all buildings include elements that are repetitive. According to Sulistijowati (1991: 12) in (Antariksa, 2010), the introduction of typology will lead to efforts to "classify", based on certain aspects or rules. These aspects include:

a) Functions (includes space, structural, symbolic, etc.);

b) Geometric (includes form, order principle, etc.); and

c) Style (includes period, location or geography, politics or power, ethnicity and culture, etc.).

From several theories, it can be concluded that typology in architecture is an attempt to classify by describing groups of objects based on a common trait. This is done until it can be revealed the diversity and similarity between them so that it makes it easier for people to recognize the characteristics of its architecture.

Whereas regarding facade, according to (Krier, 2001), the facade is a unit that has the ability to express itself and is a unity in a single element. The facade is the front of a building that faces the road and is often referred to as the face of a building.

According to Askari (2009) in (Fauziah, Nur, Antariksa, 2012), the element that best shapes the visual character of the facade is the architectural style of building facade ${ }^{10}$. From the architectural style of buildings found in an area can be identified how the character is based on facade elements in each building.

The elements that are considered in examining building facades between building units according to (Setyowati, Titik I, 2014) are as follows:

1. Facade proportion

a. Portions of openings, entrances location, door sizes, windows that arrange the ratio articulation of solid voids on the walls

b. Material building material surface and texture to produce bar motifs.

c. Colour

2. Building mass composition

a. Height of the building to create the right scale with buildings around and human scale

b. Line of front and side building borders that regulate the distance of building deterioration from existing roads and buildings

c. Mass form composition

\section{Others}

a. Architectural style

b. Landscape arrangement 


\section{Discussion}

The Kayu Tangan Street Corridor is located in the Klojen District centre of Malang City. Currently, the Kayu Tangan Street Corridor is better known as Jl. Jenderal Basuki Rahmat. The buildings physical form in this street corridor has a distinctive sense of place and character.

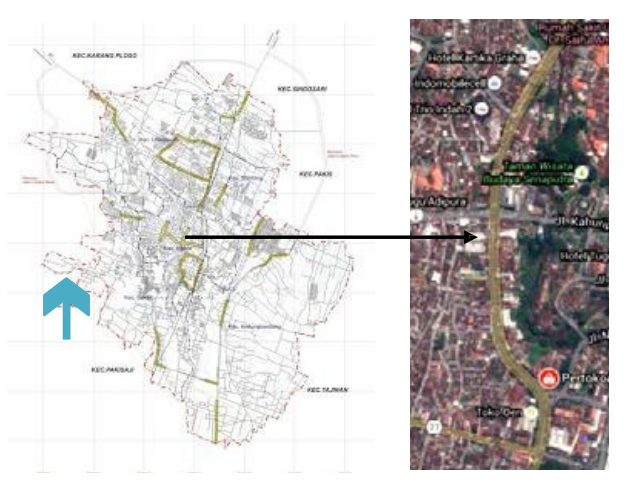

Figure 1. Study Location

(Source: google.co.id/maps)

At the beginning of its development, this area was a European settlement (Kajoetangan straat), but in subsequent developments, the region developed into a commercial area for the middle class and Europeans (Fauziah, Nur, Antariksa, 2012). Kayu Tangan has been rapidly developing into a shopping complex area with the shape and appearance of buildings lined up with interesting facade characters.

\section{Classification by function}

To find out the typological character, the building in the Kayu Tangan Road Corridor can be classified based on its function. There are several building functions found, which include:

1. Shop (trade in goods/services)

2. Office and Bank

3. Religious buildings

4. Hotels

Based on Malang City RTRW for 2009-2029, this street corridor has the function of land use as a commercial area in the form of trade and services. So, the majority of existing buildings are commercial buildings. There are no buildings with special functions in the form of residential. However, it can be found a building with a shop function on the ground floor while the upper floor is used for residential (shop houses). Shops that are located in the street corridor include trade in goods and services, as well as restaurants and cafe.

Besides shops, there can be found several offices and large banks such as BCA Bank, Panin Bank, Common Wealth Bank, and others. In this street corridor, only one building with a function of worship was found, namely the Hati Kudus Church located on the corner of the road which leads to the square of Malang City. It is also known as the Kayu Tangan Church, the mention of this name indicates the perception of the building as a landmark. The existence of this church creates a distinctive visual effect and gives a special character to the Kayu Tangan street corridor.

The commercial building with Hotel functions that can be found on this road corridor is Trio Indah 2 Hotel, which is located in the corner of Oro-oro Dowo and Riche Hotel, which is located at the boundary of the southern Kayu Tangan street corridor closed to Malang City Town Square. 


\section{Tipology of Fasade Building in Kayu Tangan Street Coridor, Malang City \\ Resti Piutanti}

From the existing classification of functions, it can be said that in addition to religious buildings, almost all of them are commercial buildings. However, with different building functions, there are also different characters in the facade and also have different effects on the visual quality of the area.

\section{Classification Based on Building Style}

Based on the style of the building, there are four types of building on the Kayu Tangan corridor $^{13}$ :

1. 83 buildings in the Nieuw Bowen style

2. 9 buildings with Nieuw Bowen Modern facade style building

3. 1 Neo-Gothic building

4. 14 Modern buildings

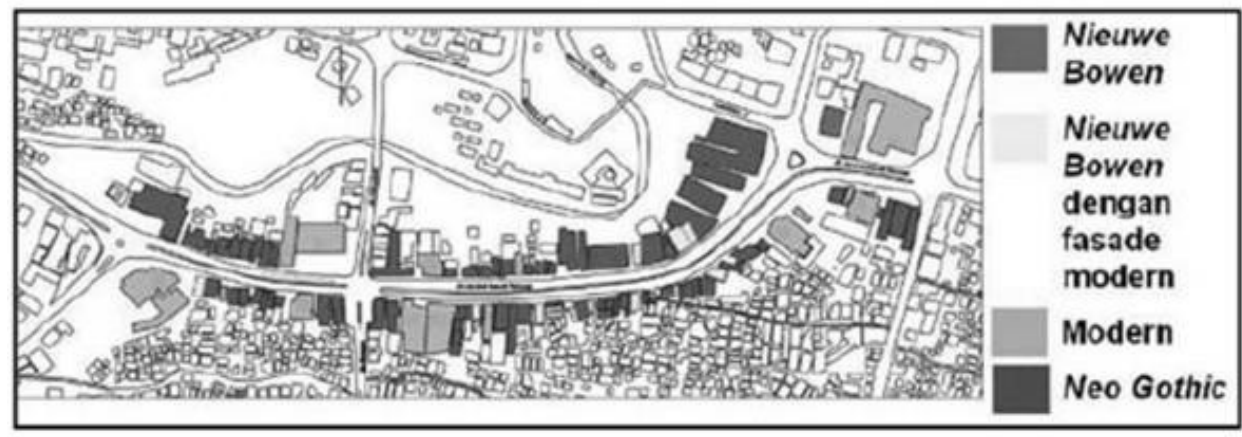

Figure 2. Building Style Classification Mapping

(Source: Fauziah, 2012)

The building with the style of Nieuw Bowen has the character with a brick wall material coated with paint and smooth texture. The Nieuw Bowen-style building with modern facade has the character of using fine-textured bricks coated with fabricated materials such as aluminium and glass, the texture is smooth and transparent. Buildings with Neo-Gothic style have a character with the use of brick material, the texture is smooth and has a distinctive geometric shape with a high roof, and there are additional towers in the church. Whereas in modern buildings, the material used is brick, with a combination of coarse and fine texture created by the dominance of fabricated materials used. 
LOCAL WISDOM, Vol. 11 No. 2 Juli 2019

Local Wisdom Scientific Online Journal

Table 1. The building of classification styles in each function

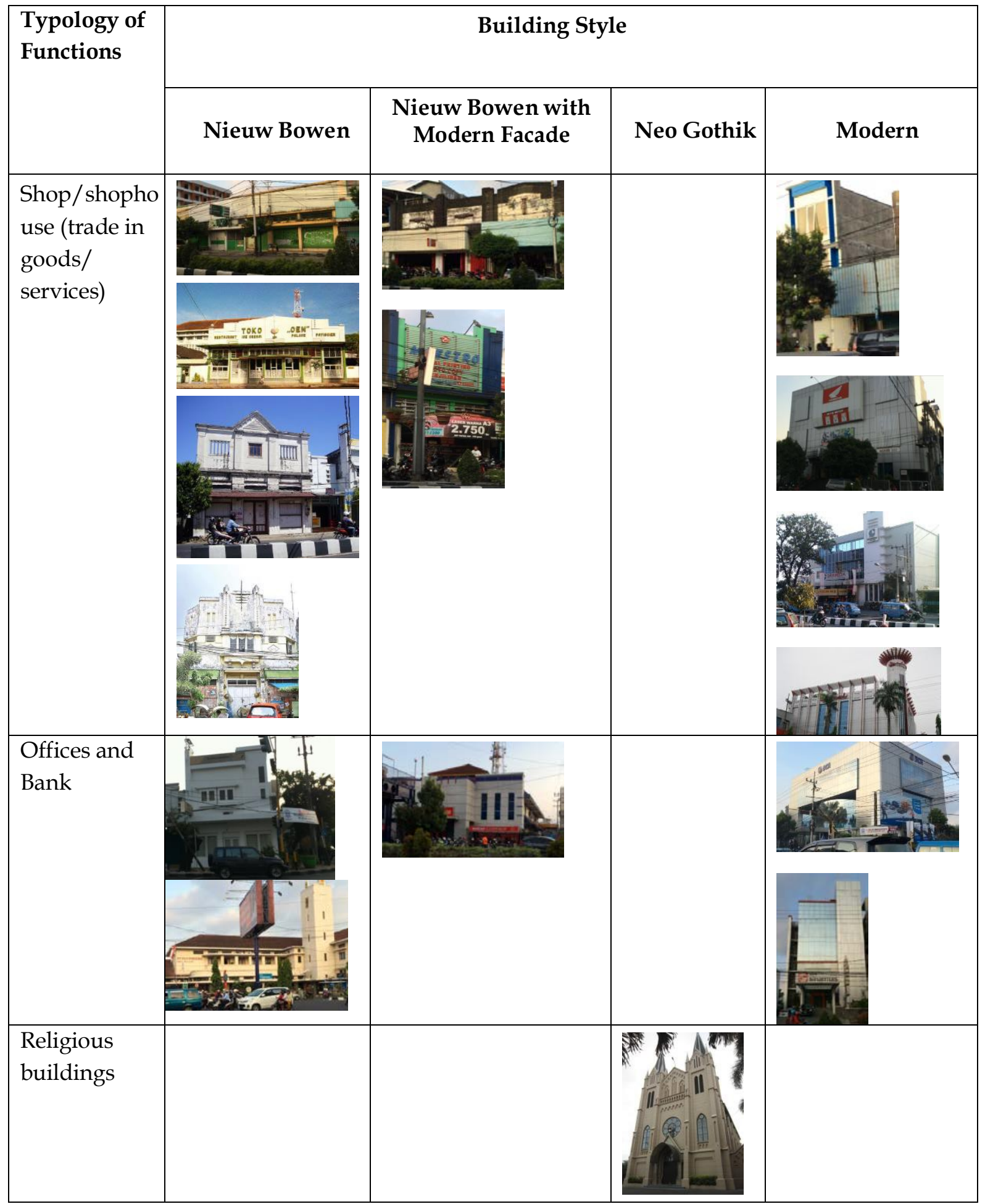




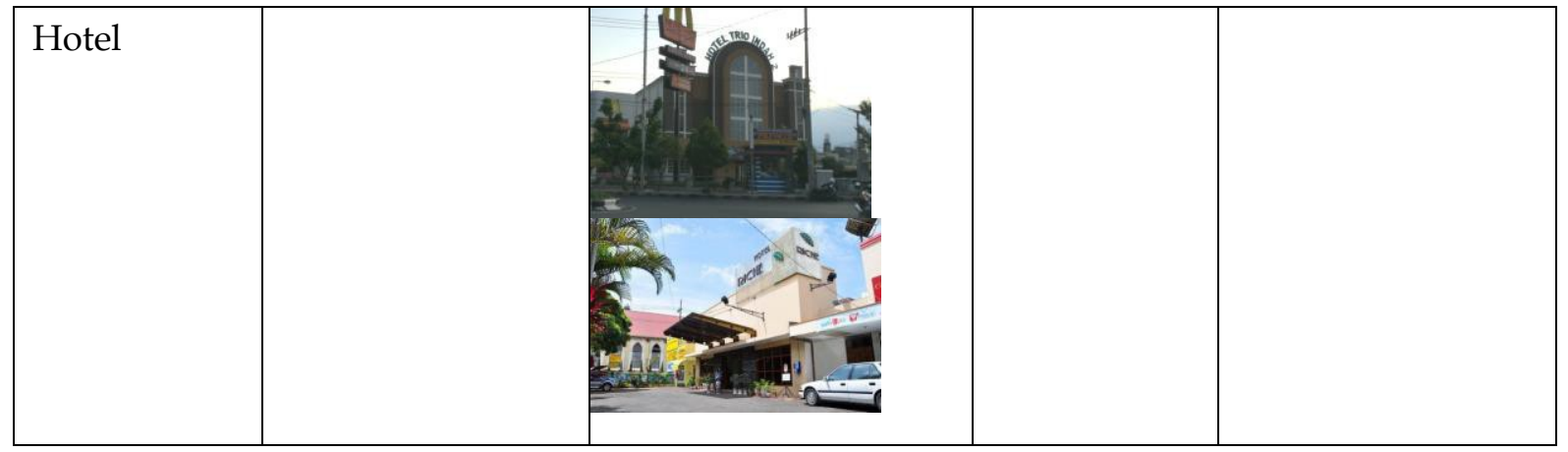

\section{Classification based on Facade Character}

From the functions and building styles classification found, each character can be identified at the facade. Such as the following:

1. Basic building geometry

The basic building geometry of each building function and style gives its own characteristics in the region. The majority of the Nieuw Bowen buildings are dominated by basic geometry in the form of a square. The diversity of basic shapes can be seen in shops and religious buildings in the style of Nieuw Bowen, Nieuw Bowen Modern façade and modern in stores and Neo-Gothic in the Church. The church has a triangular geometry that is quite prominent and the tower forms a characteristic that is unique to neo-gothic buildings.

2. The proportion of openings, doors and windows

The dominant proportion of openings can be seen in buildings with functions of shops that have a NieuwBowen style and office. It is certainly related to building needs. Openings in the shop building with Nieuw Bowen style in the form of windows lined up with balanced proportions. Whereas in a modern style office there is no living window but the facade is dominated by the glass (permanent window)

3. Number of building floors

In buildings with functions of shops/shophouses (trade in goods/services), there are 1-4 floors. In offices and banks, on average more than 3 floors. In religious buildings, the height is equivalent to 3 floors. Whereas, in building with Hotel functions there are 3-4 floors.

4. The distance of the building from the road

Buildings with shop functions are more close to the road, but the store that has a height of 3 floors, the distance is quite far from the road and there is a parking area in front of it. For modern buildings with a height of more than 3 floors, the distance is far from the road, so is the hotel. The front and side building demarcation lines regulate the distance of building deterioration from existing roads and buildings.

5. Elements of adding facades

There is no element of adding facades to Nieuw Bowen buildings style, it is found in Nieuw Bowen-style buildings with modern facades and also in modern buildings. In modern shop and offices, many found additions in the form of billboards. Whereas, in buildings with other function, the addition in the form of aluminium and or glass as an 
artificial element.

6. Special elements/prominent details

In buildings with Nieuw Bowen style, there are short window trunks, smooth wall textures, rows of windows that form horizontal lines. In the Nieuw Bowen style building with a modern facade that prominent, there are additional modern elements in the facade, and have wide doors. In modern buildings, there is no prominent detail because the shape is dominated by a minimalist square geometry. In the Neo-Gothic (Church) building there are simple carvings on the face of the building with typical and gothic geometry, the windows also function artificially, and there is a tapered roof on the front. In buildings with hotel functions no special prominent elements.

Table 2. Classification based on facade elements (1)

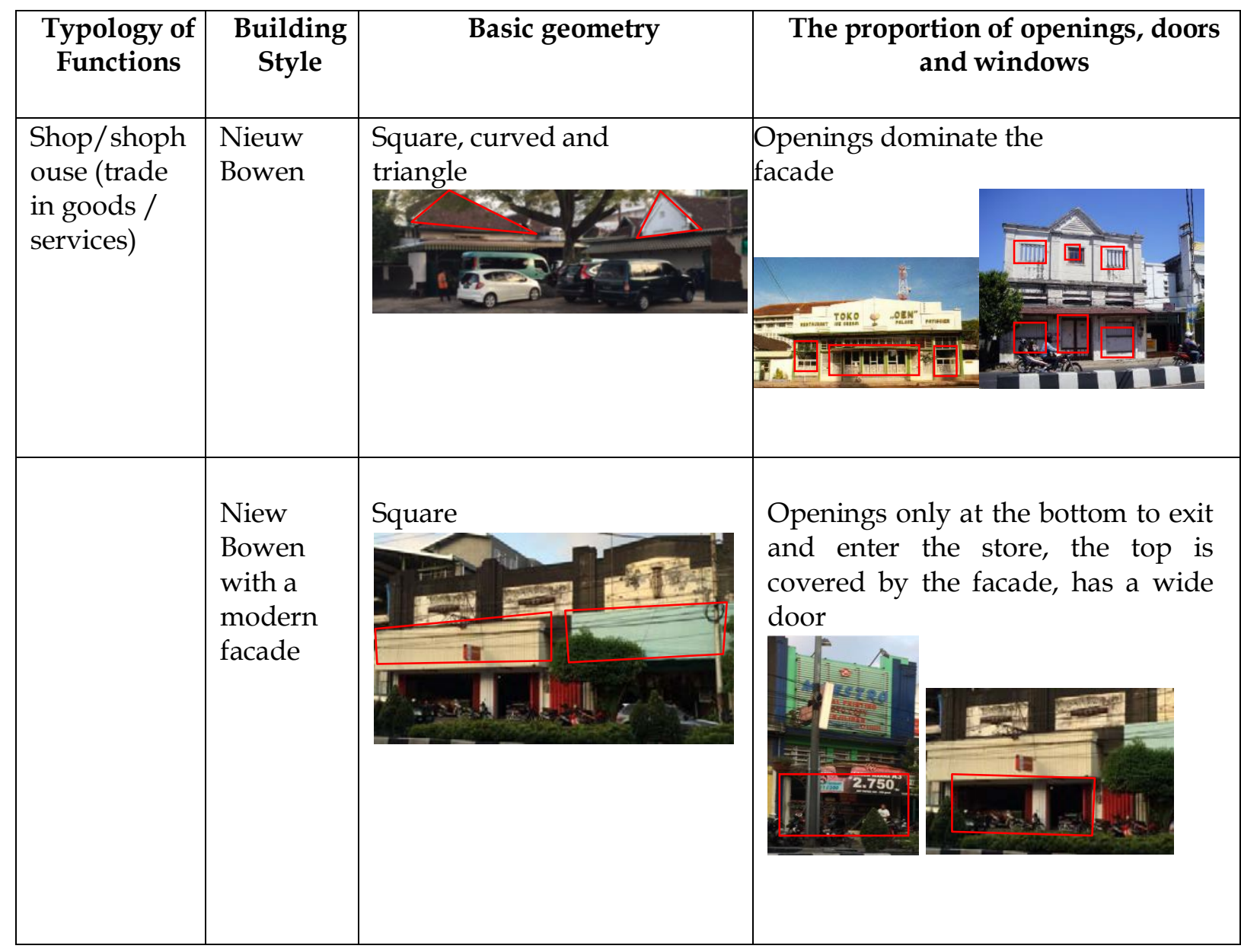




\begin{tabular}{|c|c|c|c|}
\hline & Modern & Square and curved & $\begin{array}{l}\text { There are no openings at the top of } \\
\text { the building in large stores, while the } \\
\text { shophouses have openings in the } \\
\text { form of windows. But it is still } \\
\text { dominated by the façade cover. }\end{array}$ \\
\hline $\begin{array}{l}\text { Office and } \\
\text { Bank }\end{array}$ & $\begin{array}{l}\text { Nieuw } \\
\text { Bowen }\end{array}$ & Dominated by square & Openings dominate the façade \\
\hline & $\begin{array}{l}\text { Nieuw } \\
\text { Bowen } \\
\text { with } \\
\text { Modern } \\
\text { Facade }\end{array}$ & Dominated by square & $\begin{array}{l}\text { There are openings but do not } \\
\text { dominate the facade because it is } \\
\text { enclosed in the additional facade. }\end{array}$ \\
\hline
\end{tabular}


LOCAL WISDOM, Vol. 11 No. 2 Juli 2019

Local Wisdom Scientific Online Journal

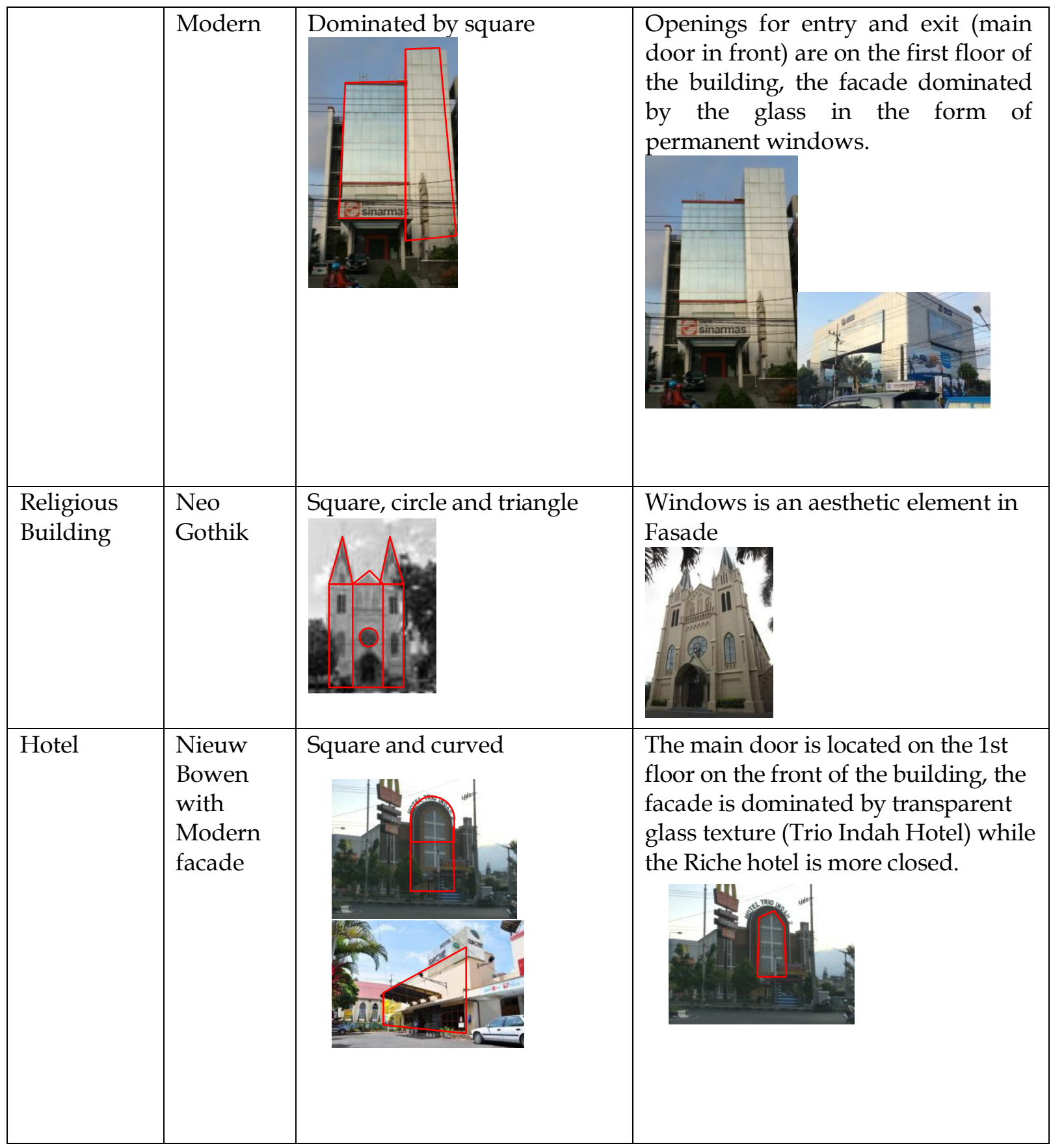


Table 3. Classification based on facade elements (2)

\begin{tabular}{|c|c|c|c|c|c|}
\hline $\begin{array}{l}\text { Typology of } \\
\text { Functions }\end{array}$ & $\begin{array}{l}\text { Building } \\
\text { Style }\end{array}$ & $\begin{array}{l}\text { Number of } \\
\text { Floors }\end{array}$ & $\begin{array}{l}\text { The distance of } \\
\text { the building } \\
\text { from the road }\end{array}$ & $\begin{array}{l}\text { Elements of } \\
\text { adding facades }\end{array}$ & $\begin{array}{l}\text { Special } \\
\text { elements/details }\end{array}$ \\
\hline \multirow[t]{3}{*}{$\begin{array}{l}\text { Shop/shoph } \\
\text { ouse (trade } \\
\text { in goods / } \\
\text { services) }\end{array}$} & $\begin{array}{l}\text { Nieuw } \\
\text { Bowen }\end{array}$ & 1-2 floor & Close to the road & $\begin{array}{l}\text { There is no } \\
\text { addition of } \\
\text { elements to the } \\
\text { facade }\end{array}$ & $\begin{array}{l}\text { Short window } \\
\text { tones, smooth wall } \\
\text { textures, rows of } \\
\text { windows }\end{array}$ \\
\hline & $\begin{array}{l}\text { Nieu } \\
\mathrm{w} \\
\text { Bowen } \\
\text { with a } \\
\text { moder } \\
\mathrm{n} \\
\text { facade }\end{array}$ & 1-2 floor & Close to the road & $\begin{array}{l}\text { Billboard, } \\
\text { aluminium for } \\
\text { artificial faces } \\
\text { on the } \\
\text { building }\end{array}$ & $\begin{array}{l}\text { Modern additions } \\
\text { to the facade of } \\
\text { Bowen Bowen, } \\
\text { wide door } \\
\end{array}$ \\
\hline & Modern & 3-4 floor & $\begin{array}{l}\text { At the shop near } \\
\text { the road, the big } \\
\text { shops (such as } \\
\text { Gramedia, etc.) } \\
\text { are a bit far } \\
\text { from the road }\end{array}$ & $\begin{array}{l}\text { Billboards, } \\
\text { glass and } \\
\text { aluminium for } \\
\text { artificial }\end{array}$ & $\begin{array}{l}\text { Minimalist square } \\
\text { shape }\end{array}$ \\
\hline \multirow[t]{2}{*}{$\begin{array}{l}\text { Office and } \\
\text { Bank }\end{array}$} & $\begin{array}{l}\text { Nieuw } \\
\text { Bowen }\end{array}$ & 1-2 floor & $\begin{array}{l}\text { The majority are } \\
\text { close to the } \\
\text { road, while the } \\
\text { PLN building is } \\
\text { quite far from } \\
\text { the road }\end{array}$ & $\begin{array}{l}\text { There is no } \\
\text { addition of } \\
\text { elements to the } \\
\text { facade }\end{array}$ & $\begin{array}{l}\text { Short window } \\
\text { tones, smooth } \\
\text { wall textures, } \\
\text { rows of } \\
\text { windows }\end{array}$ \\
\hline & $\begin{array}{l}\text { Niew } \\
\text { Bowen } \\
\text { with } \\
\text { modern } \\
\text { facade }\end{array}$ & 2-3 floor & $\begin{array}{l}\text { The majority is } \\
\text { close to the } \\
\text { road, while the } \\
\text { Telkom building } \\
\text { is quite far from } \\
\text { the road }\end{array}$ & $\begin{array}{l}\text { glass and } \\
\text { aluminium for } \\
\text { artificial } 1\end{array}$ & $\begin{array}{l}\text { A modern } \\
\text { addition to the } \\
\text { facade of the } \\
\text { bowennieuw }\end{array}$ \\
\hline
\end{tabular}


LOCAL WISDOM, Vol. 11 No. 2 Juli 2019

Local Wisdom Scientific Online Journal

\begin{tabular}{|c|c|c|c|c|c|}
\hline & Modern & $\begin{array}{l}\text { More than } 3 \\
\text { floor }\end{array}$ & $\begin{array}{l}\text { Far from the } \\
\text { road }\end{array}$ & $\begin{array}{l}\text { Billboards, } \\
\text { glass and } \\
\text { aluminium for } \\
\text { artificial }\end{array}$ & $\begin{array}{l}\text { Domination of a } \\
\text { minimalist square } \\
\text { shape }\end{array}$ \\
\hline $\begin{array}{l}\text { Religious } \\
\text { Building }\end{array}$ & $\begin{array}{l}\text { Neo } \\
\text { Gothik }\end{array}$ & $\begin{array}{l}\text { the } \\
\text { height } \\
\text { is equal } \\
\text { to } 3 \\
\text { floors }\end{array}$ & $\begin{array}{l}\text { Far from the } \\
\text { road }\end{array}$ & $\begin{array}{l}\text { There is no } \\
\text { addition of } \\
\text { elements to } \\
\text { the facade }\end{array}$ & $\begin{array}{l}\text { Simple carvings } \\
\text { on the face of } \\
\text { buildings with } \\
\text { typical and gothic } \\
\text { geometry, } \\
\text { windows also } \\
\text { function artificial, } \\
\text { tapered roofs } \\
\end{array}$ \\
\hline Hotel & $\begin{array}{l}\text { Niew } \\
\text { Bowen } \\
\text { with } \\
\text { modern }\end{array}$ & 3-4 floor & $\begin{array}{l}\text { Far from the } \\
\text { road }\end{array}$ & $\begin{array}{l}\text { Billboard and } \\
\text { glass }\end{array}$ & $\begin{array}{l}\text { There are no } \\
\text { special } \\
\text { elements }\end{array}$ \\
\hline
\end{tabular}

Visual disturbance factors of the region

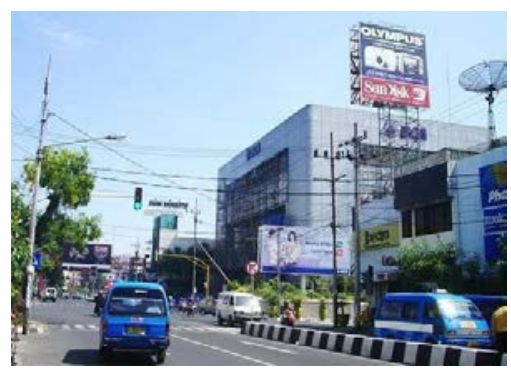

Figure 3. Billboard on the front of the building

Billboards that cross the road also identified as additional elements that damage the vista in this region and reduce the visual quality of the region. Visibility becomes narrower and road users cannot enjoy the atmosphere formed by the row of facades in this road corridor, while also adding texture and colour that contrasts with the smooth and harmonious lines of the Nieuw Bowen building. 


\section{Tipology of Fasade Building in Kayu Tangan Street Coridor, Malang City

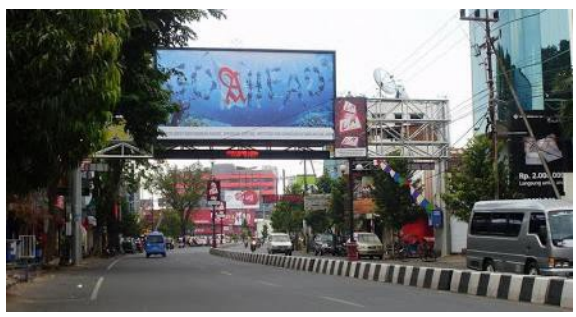

Figure 4. Billboards that cross the road

The existence of skyscraper is also one of the factors that interfere with the visual quality of the region because its existence is in stark contrast to other surrounding buildings. The dominant use of glass and aluminium also reduces the aesthetics of building shapes that had previously been composed of a row of buildings like Nieuw Bowen.

\section{Conclusion}

There is a classification of function types, namely trade/service buildings, offices \& banks, worship, and hotels. Each function type has a classification of styles, basic geometry and various floor heights. The functions of trade and service buildings have the most diverse visual features (many types) compared to other functions. The worship function has a unique (the only) building style that is neogothic. From the overall function and style, the basic geometry that unites is a square shape. From the analysis, it knew that the type of building based on its function:

1. In buildings with functions of shops/shophouses (trade in goods/services), there are 3 types of building styles, namely Nieuw Bowen, Nieuw Bowen with Modern and Modern Facade, where the basic geometry is more diverse. Moreover, the height of the building floor ranges from 1-4 floors,

2. In buildings with Office and Bank functions, there are 2 types of building styles, namely Nieuw Bowen and Modern with square base geometry. With an average height of more than 3 floors of buildings,

3. In buildings with worship functions, there is only 1 type of building style, namely NeoGothic, the height is equivalent to 3 floors of the building, the basic geometry is square and triangular,

4. In buildings with Hotel functions, only 1 building style is found, namely Nieuw Bowen with Modern Facade, where the basic geometry is square and curved with 4 floors of buildings.

\section{Ideas for Regional Development}

Currently, a number of new building construction projects are being carried out within the area kayu tangan corridor. Some of them also used demolition efforts to create buildings with new conditions. The design that is developing at this time is considered not in harmony with the visual character of the existing building. So, a reference/direction needed in the form of policies and guidelines for development. 


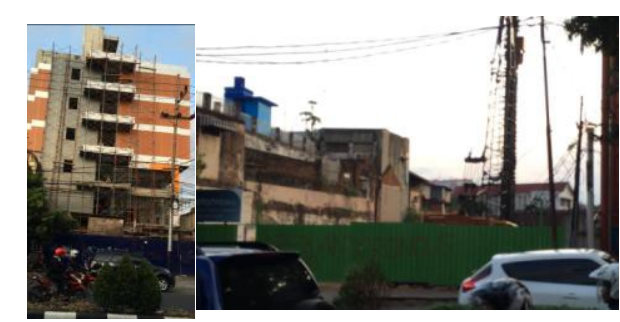

Figure 5. Demolition and construction of new buildings in Kayu Tangan

The guidelines made need to explain in detail the design elements in the building, especially on the facade of the building which will affect the visual character of the area. One of them is by adjusting the harmony of the building facade according to its function. Reference policies can be classified based on their functions.

From the existing building, functions can be maintained the characteristics of facades in a specific style such as Nieuw Bowen or Nieuw Bowen with modern facades and Neo-Gothic. Alignment between buildings is needed and efforts to reduce disturbing factors to achieve the good visual quality of the area.

\section{Refference}

Antariksa. (2010). Tipologi Wajah Bangunan dan Riasan dalam Arsitektur Kolonial Belanda.

Fauziah, Nur, Antariksa, J. ernawat. (2012). Karakter Visual Fasade Bangunan di Koridor Jalan Kayutangan Malang. In Seminar Nasional Menuju Arsitektur berEmpati (pp. 175-184).

Galih W. Pangarsa, Ema Y. Titisari, Abraham M. Ridjal, J. E. (2012). Tipologi Nusantara Green

Architecture Dalam Rangka Konservasi Dan Pengembangan Arsitektur Nusantara Bagi

Perbaikan Kualitas Lingkungan Binaan. Jurnal RUAS, 10(2), 78-94. Retrieved from https:/ / ruas.ub.ac.id/index.php/ruas/article/view/114/116

Krier, R. (2001). Komposisi Arsitektur (architectural composition.). Erlangga, 2001.

Prijotomo, J. S. (1997). Bunga Rampai Arsitektur ITS Surabaya. Surabaya: Bunga Rampai Jurusan

Arsitektur Fakultas Teknik Sipil dan Perencanaan Institut Teknologi Sepuluh November Surabaya.

Setyowati, Titik I, A. (2014). Tipologi Fasade Bangunan Di Jalan Kawi Atas Kota Malang. Jurnal

Mahasiswa Jurusan Arsitektur, 2(2). Retrieved from

http://arsitektur.studentjournal.ub.ac.id/index.php/jma/article/view/56/56 